Liturgia Sacra 24 (2018), nr 1, s. 199-228

DOI: $10.25167 / \mathrm{LitS} / 24(2018) 1 / 199-228$

IRINA CHACHULSKA

Instytut Sztuki PAN

\title{
O notacjach muzycznych $w$ antyfonarzu tynieckim
}

Wyjątkowe walory artystyczne pochodzącego sprzed 1409 r. antyfonarza opata Mścisława (Pl-Wn $12720 \mathrm{~V})^{1}$ od początku XX stulecia niezmiennie wzbudzają żywe zainteresowanie polskich historyków sztuki ${ }^{2}$. Spośród zachowanych kodeksów tynieckich stawiany jest on na pierwszym miejscu pod względem kunsztu malarskiego ${ }^{3}$ i zaliczany do grupy znaczących dzieł malarstwa małopolskiego ${ }^{4}$. Nie mniej ważne znaczenie rękopis ten posiada jako księga liturgiczna, stanowiąc niezwykle cenne źródło dla badań nad benedyktyńską tradycją muzyczno-liturgiczną w Polsce oraz diastematyczną notacją średniowiecznych ksiąg o rodzimej proweniencji. Szczególny zabytek stanowi antyfonarz opata Mścisława jako źródło muzyczne, nie tylko bowiem dokumentuje on jedną z wówczas używanych notacji muzycznych w skryptorium tynieckim, ale jest także świadectwem ewolucji pisma muzycznego w tymże skryptorium, zawierając poza zasadniczą notacją kwadratową, różne formy notacyjne - zarówno w warstwie pierwotnej (oryginalnej), jak

${ }^{1}$ Poprzednia sygnatura antyfonarza: akc. 10808 (Biblioteka Narodowa); Antyfonarz tyniecki jest także dostępny na portalu internetowym Polona, https://polona.pl/item/20758739/0/, (1.09.2017). Rękopis został zredagowany przez opata Mścisława i spisany przez katedralisa Przybysława przed rokiem 1409: Explicit liber de tempore per manus Przibislai Kathedralis compilus per reverendum in Christo paterm diuina prouidencia matislaum abbatem Tinciensem orate pro eis (zob. f. 352v).

${ }^{2}$ Wykaz ważniejszych prac z zakresu historii sztuki: W. PodLAcha, Miniatury tynieckich ksiag liturgicznych w Bibliotece Uniwersyteckiej we Lwowie, w: Ksiegga pamiatkowa ku czci Bolesława Orzechowicza, t. II, Lwów 1916; F. KOPERA, Dzieje malarstwa w Polsce. Sredniowieczne malarstwo $w$ Polsce, t. I, Kraków 1925; B. MiodońSKa, Kodeksy iluminowane benedyktynów tynieckich. Wieki $X I V-X V$ (Uwagi historyka sztuki), w: K. ŻURowsKa (red.), Ksiegga pamiątkowa ku czci Bolesława Orzechowicza Benedyktyni tynieccy w średniowieczu. Materiaty z sesji naukowej Wawel - Tyniec, 13-15.10.1994, Tyniec - Kraków 1995, s. 243-260; K. ŻurowsKA (red.), Tyniec. Sztuka i kultura benedyktynów od wieku XI do XVIII. Katalog wystawy w Zamku Królewskim na Wawelu, październikgrudzień 1994, Kraków 1994; G. KLIMECKA: Tynieckie rękopisy iluminowane w zbiorach Biblioteki Narodowej przykładem benedyktyńskiej kultury piśmienniczej w XIV-XV w., w: A. PoBóG-LenARTowicz, M. DerWICH (red.), Klasztor w kulturze średniowiecznej Polski, Opole 1995, s. 289-297.

3 W. Podlacha, Miniatury tynieckich ksiag, s. 199.

${ }^{4}$ B. MiodońsKa, Kodeksy iluminowane benedyktynów, s. 244-245. 
i późniejszej (fragmenty palimpsestowe, wpisy na marginesach, dodane karty) kształtujące się w tym skryptorium w ciągu wielu lat.

Wśród mediewistów-muzykologów zainteresowanie tym rękopisem pojawia się dopiero pod koniec XX w.. Początkowo prace, których autorzy włączają do listy badanych źródeł także antyfonarz tyniecki, poświęcone są tylko i wyłącznie zagadnieniu notacji - wymienić tu należy publikacje ks. Tadeusza Miazgi z 1984 roku: Notacja gregoriańska w świetle polskich rękopisów liturgicznych ${ }^{5}$ i Janki Szendrei z 1999 roku: Notacja liniowa w polskich źródłach choratowych XII-XVI wieku ${ }^{6}$. W pierwszej z nich autor ogranicza się jedynie do stwierdzenia, iż kodeks został sporządzony w notacji kwadratowej i tylko tę notację analizuje ${ }^{7}$. Z kolei w drugiej - publikacji J. Szendrei - poza krótkim scharakteryzowaniem zasadniczej notacji muzycznej rękopisu (kwadratowej) autorka wskazuje także na odmienny zapis muzyczny folio 1r (zapis oryginalny), oparty na systemie mieszanych neum metzeńsko-gotyckich, oraz dodaje, iż ,poprawki w zapisie muzycznym tego kodeksu wprowadzono w notacji gotyckiej”». J. Szendrei nie precyzuje jednak rodzaju notacji gotyckiej zastosowanej w owych poprawkach, nie podejmuje także problemu występowania różnych form notacyjnych w nieoryginalnej warstwie rękopisu (korekty, zapisy na marginesach) oraz nie mówi nic o notacji kart papierowych dołączonych do księgi prawdopodobnie pod koniec XVI w. ${ }^{9}$

Na początku kolejnego stulecia antyfonarz doczekał się całościowego opracowania źródłowego. W 2009 r. ukazała się monografia pt. Antyfonarz Mścisława z Tyńca. Studium źródtoznawcze ${ }^{10}$ autorstwa ks. Tadeusza Bratkowskiego - polskiego muzykologa i teologa. Autor przedstawia obszerny opis fizyczny rękopisu,

5 T. MiazGa, Notacja gregoriańska w świetle polskich rękopisów liturgicznych, Graz 1984.

6 J. SzendreI, Notacja liniowa w polskich źródłach chorałowych XII-XVI wieku, w: E. WiTKowSKa-Zaremba (red.), Notae musicae artis. Notacja muzyczna w źródtach polskich XI-XVI wieku, Kraków 1999, s. 187-281; Poza dwiema wspomnianymi publikacjami należałoby także wymienić pracę Bartosza Izbickiego poświęconą graduałowi opata Mścisława, w której autor do źródeł porównawczych włącza także antyfonarz tyniecki opata Mścisława. B. IzBIcki, Graduał tyniecki ms. b. s. I w świetle tradycji europejskiej i polskiej. Studium źródtoznawcze, Warszawa 2006 (mps pracy doktorskiej w Bibliotece UKSW).

7 T. MiazGa: Notacja gregoriańska, s. 99.

8 J. Szendrei, Notacja liniowa, s. 206. Wspomniane przez autorkę „poprawki” pojawiają się w antyfonarzu nie tylko w notacji gotyckiej, ale także w notacji kwadratowej.

${ }^{9}$ Pominięcie tych kwestii przez autorkę wynika prawdopodobnie z charakteru jej pracy, przedstawiającej w pierwszym rzędzie ogólny obraz notacji muzycznej (liniowej) w polskich średniowiecznych źródłach chorałowych.

10 T. Bratkowski, Antyfonarz Mścisława z Tyńca. Studium źródłoznawcze, Przemyśl 2009. Jest to publikacja dysertacji autora pt. Antyfonarz Mścisława z Tyńca w świetle tradycji polskiej i europejskiej. Studium źródłoznawcze, napisanej pod kierunkiem ks. prof. dra hab. Jerzego Pikulika w Katedrze Źródeł i Analiz Muzyki Dawnej UKSW (2003 r.). 
pisze o pochodzeniu księgi i jej losach późniejszych, jako pierwszy szczegółowo omawia zawartość rękopisu oraz dokonuje zestawienia repertuaru antyfonarza tynieckiego z repertuarami ważniejszych źródeł zachodnioeuropejskich tegoż okresu. Niemniej, kwestia pisma muzycznego poza notacją zasadniczą (kwadratową) została potraktowana dość marginalnie. Bratkowski wspomina jedynie o występowaniu w rękopisie innego rodzaju notacji niż kwadratowa, przy czym, po pierwsze, jako miejsca występowania innej notacji podaje tylko pierwszą kartę i dołączone do rękopisu w czasie późniejszym karty papierowe, po drugie zaś, nie czyni rozróżnienia nawet pomiędzy tymi dwoma wariantami gotyckiego pisma muzycznego - pisma karty 1r i notacji kart papierowych - określając je ogólnie jako notację rombową ${ }^{11}$, co wydaje się zbyt dużym uproszczeniem. Z kolei o sposobach notacji wpisów marginesowych czy też licznych korekt w trakcie rękopisu autor milczy.

Dotychczas kwestia pisma muzycznego należącego do nieoryginalnej warstwy antyfonarza tynieckiego (późniejsze zapisy na marginesach, korekty, karty dodane później) albo była całkowicie pomijana w literaturze przedmiotu, albo też traktowana marginalnie. Wpisy późniejsze mogą stanowić jednak ważne świadectwo nie tylko pewnej praktyki liturgicznej (repertuarowej) w danym ośrodku, ale i praktyki piśmienniczej - znajomości i stosowania określonych systemów notacyjnych, a czasem i ewolucji pisma muzycznego $\mathrm{w}$ danym skryptorium - w tym przypadku skryptorium tynieckim.

Antyfonarz tyniecki dokumentuje różne systemy notacyjne. Już w samej warstwie oryginalnej mamy i notację kwadratową (il. 1) - podstawową notację księgi i pismo metzeńsko-gotyckie (folio 1r-il. 2). Także w zapisach późniejszych posłużono się zarówno notacją kwadratową, jak i różnymi formami pisma gotyckiego. Zamiarem niniejszego studium jest ukazanie tych różnorodnych form zapisu muzycznego obecnych w benedyktyńskim antyfonarzu tynieckim, dokumentujących tradycję piśmienniczą skryptorium tynieckiego.

Zasadnicza notacja kodeksu benedyktyńskiego (kwadratowa) została całościowo - zapis neumatyczny wraz z wszystkimi elementami notacyjnymi (kustosz, klucze itp.) - opisana we wspomnianych pracach ks. Tadeusza Miazgi, ks. Tadeusza Bratkowskiego oraz scharakteryzowana przez J. Szendrei, która jako pierwsza zauważyła wyjątkowość tego systemu neumatycznego ze względu na ukierunkowanie wszystkich elementów w prawo oraz zwróciła uwagę na jego wyjątkowo rzadkie zastosowanie w polskich zabytkach średniowiecznych (przykład 1$)^{12}$.

11 Tamże, s. 40-41.

12 J. SzEndRei, Notacja liniowa, s. 206. 


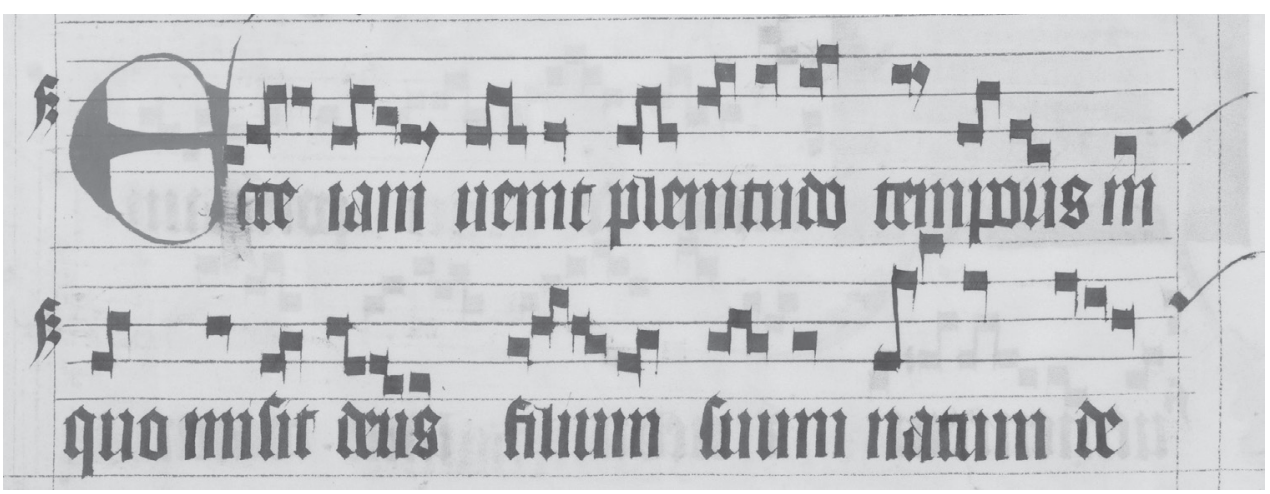

Przykład 1: Fragment ant. Ecce jam venit, f. 2r

Wyczerpującą analizę tynieckiego pisma kwadratowego przedstawiają wspomniane publikacje poświęcone antyfonarzowi opata Mścisława, zaś niniejsze studium zostanie poświęcone pozostałym formom zapisu muzycznego w tym rękopisie.

\section{Pismo muzyczne pierwszej karty antyfonarza}

Zapis, należący do warstwy oryginalnej rękopisu, ale prezentujący inny rodzaj notacji niż ta zasadnicza - notacja kwadratowa - obejmuje pismo muzyczne pierwszej karty rękopisu, a dokładnie tylko folio 1r (il. 2), oraz krótki fragment na folio $133 \mathrm{v}$ (przykład 2) - inicjum antyfony Cum jejunatis ${ }^{13}$.

Pismo to stanowi system neum mieszanych metzeńsko-gotyckich (tabela 1). Podobnie jak i w zasadniczym systemie notacyjnym rękopisu (notacji kwadratowej), neumy są zapisane na pięciu czerwonych liniach ${ }^{14} \mathrm{z}$ kluczami literowymi $c$ i $F^{15}$. Forma kustosza zastosowana na folio $1 \mathrm{r}$ - romb z cienką wstępującą na ukos kreseczką (il. 2) - jest jedną z najczęściej używanych form w tym rękopisie, choć prawdopodobnie nienależącą do zapisu oryginalnego. Podstawowym znakiem sylabicznym muzycznego pisma pierwszej karty rękopisu jest romb, w większości przypadkach zapisany z cienką ukośną kreseczką wprowadzającą. Znak ten wyraża punctum, odpowiada neumom jednoelementowym (izolowanym) - virdze czy trac-

${ }^{13} \mathrm{~W}$ dotychczasowej literaturze przedmiotu notacja tego krótkiego fragmentu nie była utożsamiana z pismem pierwszej karty.

${ }^{14}$ Praktyka kolorowania liniatury na czerwono pochodzi ze skryptoriów lotaryńskich. Por. J. Szendrei, Notacja liniowa, s. 213.

15 Od f. 1v pojawia się także klucz $g$. 


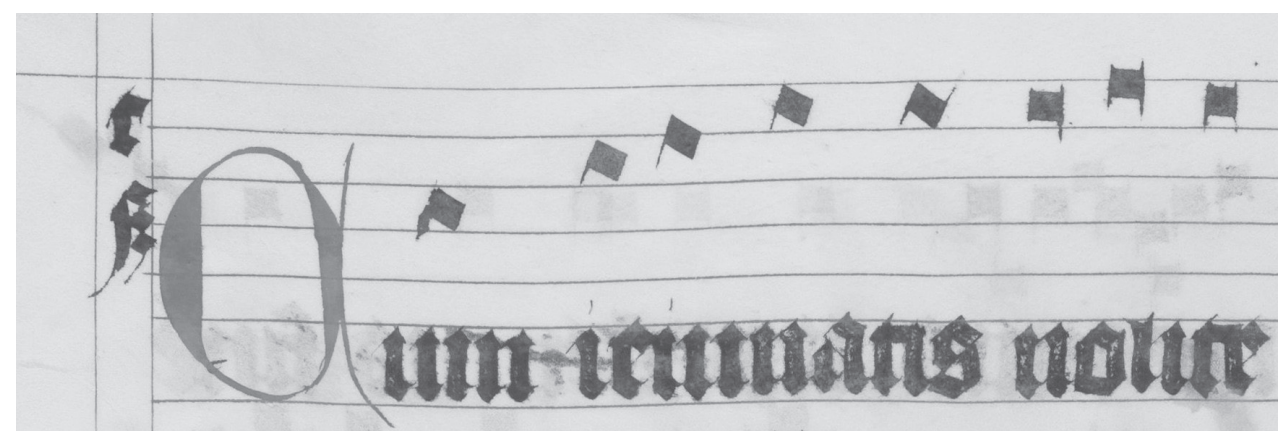

Przykład 2

tulus, oraz jest stosowany jako pierwszy element neumatyczny neum kilkudźwiękowych: pes, clivis, torculus czy climacus (tabela 1). Z kolei virga, jako element neumatyczny neumy kilkunutowej czy też grupy neumatycznej, jest zapisywana z cienką pionową kreseczką i główką o kształcie zbliżonym do rombu skierowaną w prawo, jak np. drugi element neumatyczny w pes. Dla clivis użyto tylko jednej formy - prostokątnej typu metzeńskiego, a oba jej elementy neumatyczne stanowią romby (pierwszy z kreseczką wprowadzającą) połączone grubą pionową laseczką u góry ściętą na ukos. Pes tworzą romb ze wstępną kreseczką i virga z laseczką schodzącą nieco poniżej pierwszego elementu neumatycznego w przypadku mniejszych interwałów. Podobnie jak pes rozpoczyna się neuma torculus; główka jego drugiego elementu (virga) zlewa się z masywną laseczką opadającą stromo w dół i prowadzącą do trzeciego dźwięku również zaznaczonego poprzez romb. Climacus pojawia się tylko $\mathrm{w}$ jednej formie, ukształtowanej z postępujących $\mathrm{w}$ prawo romboidalnych puncta z zaopatrzonymi, najczęściej, lecz nie zawsze, w bardzo krótkie ukośne kreseczki początkowe. Nuta likwescencyjna zaznaczona jest poprzez dodanie elementu neumatycznego w kształcie przecinka, a strophici stanowią dwa stykające się romby. $Z$ powodu posłużenia się tą notacją jedynie w tak krótkim fragmencie rękopisu, brakuje niektórych neum podstawowych, np. porrectus czy scandicus (pojawia się tylko scandicus flexus).

Neumy metzeńsko-gotyckie, które spotykamy na pierwszej karcie antyfonarza, W swoim stylu przypominają praktykę krakowską ${ }^{16}$. Stanowią one jednak dość szczególną notację, która z jednej strony wyraźnie prezentuje typ notacji gotyckiej, $\mathrm{z}$ drugiej zaś zawiera $\mathrm{w}$ sobie elementy będące efektem zabiegów zmierzających w kierunku pisma kwadratowego: wyszczuplenie oraz wyprostowanie laseczki virgi (tabela 1; zob. także: il. 2).

16 J. Szendrei, Notacja liniowa, s. 229. 
Tabela 1

\begin{tabular}{|c|c|}
\hline punctum & \\
\hline pes & \\
\hline clivis & \\
\hline climacus & \\
\hline torculus & \\
\hline strophici & \\
\hline likwescencja & \\
\hline
\end{tabular}

Interesujące spostrzeżenie dotyczące notacji pierwszej karty benedyktyńskiego antyfonarza tynieckiego poczynił w swojej pracy - poświęconej co prawda nieco starszemu kodeksowi tynieckiemu, graduałowi opata Mścisława ${ }^{17}$ - Bartosz Izbicki. Analizując pismo muzyczne graduału, poza swoistą benedyktyńską notacją tyniecką ${ }^{18}$ wyróżnia on jeszcze trzy inne warianty pisma muzycznego pojawiające się w rękopisie ${ }^{19}$, z których jedno - zastosowane na siedmiu kartach księgi: 297-303 ${ }^{20}$, określone przez autora jako „wariant czwarty” (przykład 3a) - utożsamia z notacją f. 1 antyfonarza (przykład 3b).

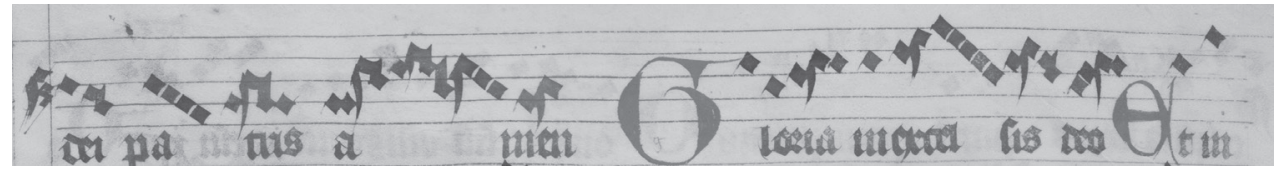

Przykład 3a: Graduał opata Mścisława, f. 301v

${ }_{17}$ Graduał jest datowany przez historyków sztuki na około 1390 rok, natomiast B. Izbicki wskazuje na początek XV w. Zob. B. IzBICKI, Graduat, s. 190.

18 Określenie notacji „tynieckiej” wprowadziła po raz pierwszy do literatury przedmiotu J. Szendrei. Zob. J. SzendreI, Notacja liniowa, s. 229-232.

${ }^{19}$ B. Izbicki w swojej pracy przedstawia tabelę obejmującą różne warianty pisma muzycznego graduału. B. IzBICKI, Graduat, s. 64.

${ }^{20}$ Autor nie wspomina o późniejszych zapisach na niektórych z tych kart - f. 297v, 298r, 299r, $303 v$ - prezentujących późną notację gotycką (późną krakowską). 


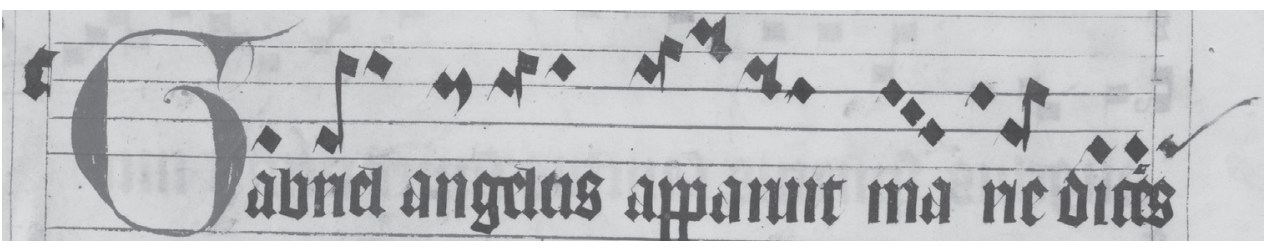

Przykład 3b: Antyfonarz opata Mścisława, f. 1r

Struktura i styl niektórych neum notacji antyfonarza i graduału są rzeczywiście tożsame. Zarazem jednak nie można nie zauważyć pewnych różnic. Przede wszystkim należałoby zaznaczyć, iż w przeciwieństwie do pierwszej karty antyfonarza, zapis na kartach graduału z notacją metzeńsko-gotycką („,czwartym wariantem” notacji) cechuje brak konsekwencji w stosowaniu znaków oraz pewna niedbałość, sprawiające wrażenie pośpiechu w sporządzaniu tego końcowego fragmentu kodeksu. Pierwsze, co zwraca uwagę w piśmie graduału, to zdecydowanie częstszy zapis virgi z nieco grubszą i lekko wygiętą laseczką (np. w neumach pes czy torculus, por. przykłady 3a i 3b). Ponadto ,czwarty wariant” notacji poza formą clivis, odpowiadającą notacji antyfonarza (f. 1r), zawiera także inne formy graficzne tej neumy mniej lub bardziej zbliżone do clivis kwadratowej - z wyraźnie cieńszą laseczką, nieco większymi i bardziej wypoziomowanymi główkami nutowymi, a czasem wręcz - głównie dotyczy drugiego elementu clivis - w formie kwadratu (przykład 4, zob. f. 297r graduału) ${ }^{21}$.

Przykład 4

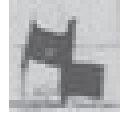

$\mathrm{Z}$ jednej strony na kartach graduału $\mathrm{z}$ „czwartym wariantem” pisma muzycznego występują formy neumatyczne zbieżne z notacją antyfonarza, $\mathrm{z}$ drugiej zaś pojawiają się tu tak odmienne zapisy niektórych neum, że trudno mówić o tożsamości tych dwóch notacji ${ }^{22}$. Co więcej, pismo muzyczne prezentowane na kartach graduału nie stanowi zwartego systemu neumatycznego, lecz wydaje się pewną „mieszaniną” form stosowanych czy powstających wówczas w danym skryptorium. Zatem określenie zapisu muzycznego na kartach 297-303 jako jednego pewnego wariantu wydaje się nazbyt ogólnikowe, należałoby wówczas nie brać pod

${ }^{21}$ Tożsamą formę clivis obejmuje „trzeci wariant” pisma muzycznego graduału. Por. B. IzBICKI, Graduat, s. 64.

${ }^{22}$ Skromny materiał muzyczny w przypadku antyfonarza - tylko jedna karta - nie wydaje się tu być powodem braku większości odmiennych form neumatycznych występujących w graduale, gdyż zapis ten charakteryzuje duża staranność i konsekwencja. 
uwagę form pośrednich - tych, które już nie są formami gotyckimi, ale jeszcze nie w pełni ukształtowanym zapisem kwadratowym (najczęściej dotyczy to neum clivis, porrectus czy torculus).

Choć notacji antyfonarza nie da się określić jako tożsamej z pismem muzycznym omawianych kart graduału, to z pewnością można śledzić związek pomiędzy oboma zapisami. Co więcej, bardzo prawdopodobne, iż z tegoż właśnie pisma się wywodzi.

Pewną ciekawostką w antyfonarzu są zapisy na marginesach, powstałe najprawdopodobniej w okresie sporządzania samego rękopisu, ewentualnie tuż po nim, w których na pierwszy rzut oka wydaje się zastosowana notacja tożsama z pismem pierwszej karty antyfonarza, lecz w rzeczywistości napotykamy tu różne odsłony notacyjne tych samych struktur neumatycznych charakterystyczne dla pism tego skryptorium na przełomie wieków XIV i XV. Szczególnie interesujące pod tym względem są dwa zapisy sporządzone na lewym marginesie folio 41v oraz prawym marginesie folio 335r (przykłady 5 i 6).

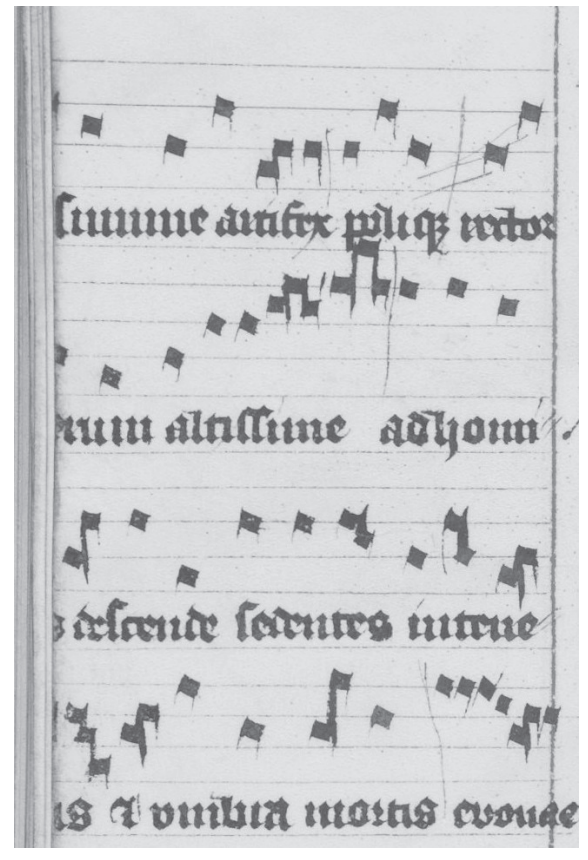

Przykład 5: f. 41v, lewy margines

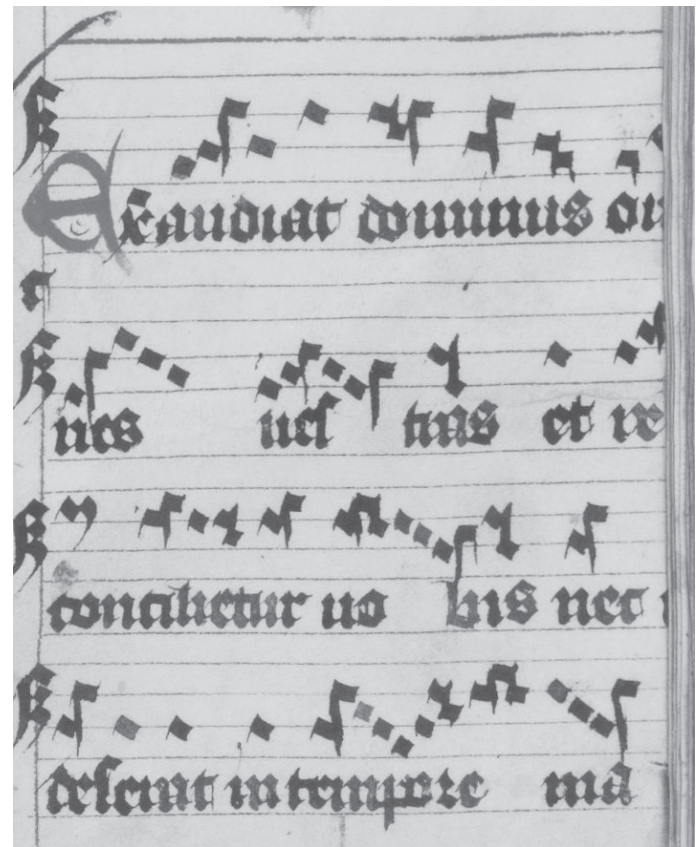

Przykład 6: f. 335r, prawy margines

W jednym z zapisów marginesowych - antyfonie O summe artifex (przykład 5) występują aż trzy formy neumy pes: metzeńsko-gotycka, składająca się z dwóch rombów, tyniecka, której pierwszy element stanowi romb, drugi zaś kwadrat, oraz 
forma kwadratowa - obie główki nutowe w kształcie kwadratu. Czasem sposób zapisu elementów neumy pes jest dość niejednoznaczny - z główką zbliżoną do formy kwadratowej, lecz jeszcze lekko pochyłą - taka forma „pośrednia”. W tejże antyfonie notator posłużył się metzeńsko-gotycką clivis, podczas gdy dla torculus użył notacji kwadratowej (zapis nie zawsze oczywisty, jeśli chodzi o główki nutowe). Z kolei virga czy tractulus (izolowane) zanotowano głównie za pomocą rombu (kwadrat pojawia się tylko dwa razy w pierwszym systemie), choć niektóre główki nut są dość wypoziomowane. Virga jako element neumatyczny neumy kilkudźwiękowej posiada pionową kreseczkę, raczej cienką.

Inny przykład o podobnym charakterze, w którym zastosowano dla jednej i tej samej neumy różne warianty graficzne kształtujące się wówczas w skryptorium tynieckim, stanowi zapis antyfony Exaudiat dominus na prawym marginesie karty $335 \mathrm{r}$ (przykład 6). Zapis muzyczny tej antyfony zasadniczo odpowiada notacji ,czwartego wariantu" pisma graduału tynieckiego. Podobnie jak w poprzednim przykładzie (przykład 5), niektóre główki nut wyraźnie dążą do poziomego położenia, np. pierwszy pes w drugim systemie (oratio-nes) z niemal poziomą (kwadratową) drugą główką jest już zbliżony do formy tynieckiej (ale nie z tak cienką laseczką).

Zapisy główek poszczególnych nut - nieraz poprzez romby, nieraz tylko jako lekko pochyłe, a czasem niemal jako kwadraty - wydają się tu być nieraz kwestią przypadku, prawdopodobnie wynikającą z charakteru samego zapisu, jakim jest zapis marginesowy, i posługiwania się przez notatora różnymi formami zapisu $\mathrm{w}$ jego skryptorium. Zasób wszystkich form neumatycznych nie wykracza poza zestaw znaków występujących w obrębie różnych wariantów pisma muzycznego graduału opata Mścisława i notacji antyfonarza.

Znamienne, iż mimo w pełni ukształtowanego kwadratowego systemu notacyjnego, gotycyzowane neumy metzeńskie, z których tenże system prawdopodobnie się wywodzi, ciągle były w użyciu. Co więcej, owe zapisy na marginesach dokumentują także ślady - być może pozostałości - notacji tynieckiej, znanej nam dotychczas jedynie z jednego nieco wcześniejszego źródła - graduału opata Mścisława.

Z jednej strony na przykładzie antyfonarza i graduału fundacji opata Mścisława śledzić można ewolucję pisma muzycznego w tym skryptorium - od notacji metzeńsko-gotyckiej poprzez swoistą notację tyniecką do pisma kwadratowego ${ }^{23}$, z drugiej zaś mocne przywiązanie do form gotyckich, poświadczane przez wpisy na marginesach $\mathrm{w}$ antyfonarzu oraz fragment końcowy w graduale.

${ }^{23}$ Szerszą analizę przemian stylistycznych przedstawia w swej pracy Bartosz Izbicki. B. IzBICKI, Graduat, s. 58-72. 


\section{Zapisy późniejsze na kartach rękopisu}

Antyfonarz tyniecki bogaty jest w liczne wpisy późniejsze, naniesione już po sporządzeniu księgi. Korekty śpiewów, zapisy na marginesach czy też większe fragmenty palimpsestowe pojawiają się niemal na całej przestrzeni rękopisu. Dodatki czy poprawki późniejsze charakteryzują się dużą różnorodnością pod względem ich pisma muzycznego. Zostały one wprowadzone przez kilku notatorów i zapewne w różnym czasie. W ten sposób księgę dostosowywano do nowych potrzeb i wymogów liturgicznych, co z kolei stanowi dowód na jej ciągłe używanie w modlitwach wspólnotowych mnichów ${ }^{24}$.

Wiele późniejszych wpisów - szczególnie jeśli chodzi o drobniejsze poprawki, ale także wpisy większych fragmentów w miejscach usuniętych kompozycji poprzednich - wprowadzono w notacji kwadratowej. W stosunku do pisma oryginalnego rękopisu są to zapisy wyraźnie późniejsze. Element w kształcie przecinka, swoisty dla zjawiska likwescencji, występuje tu w celu uwypuklenia dźwięku kończącego frazę muzyczno-słowną, w takich miejscach pojawia się też czasem kreska divisio maior (np. f. 119r, 220r). W niektórych wpisach występują na czterolinii także małe pochyłe w prawo kreseczki oddzielające krótkie struktury melodyczne odpowiadające poszczególnym wyrazom (przykład 7). Pomimo wprowadzania różnych późniejszych elementów notacyjnych zachowana zostaje szczególna cecha oryginalnej notacji kwadratowej antyfonarza - ukierunkowanie wszystkich elementów w prawo (druga główka nutowa pes znajduje się po prawej stronie laseczki, a elementy neum scandicus czy climacus postępują w prawo).

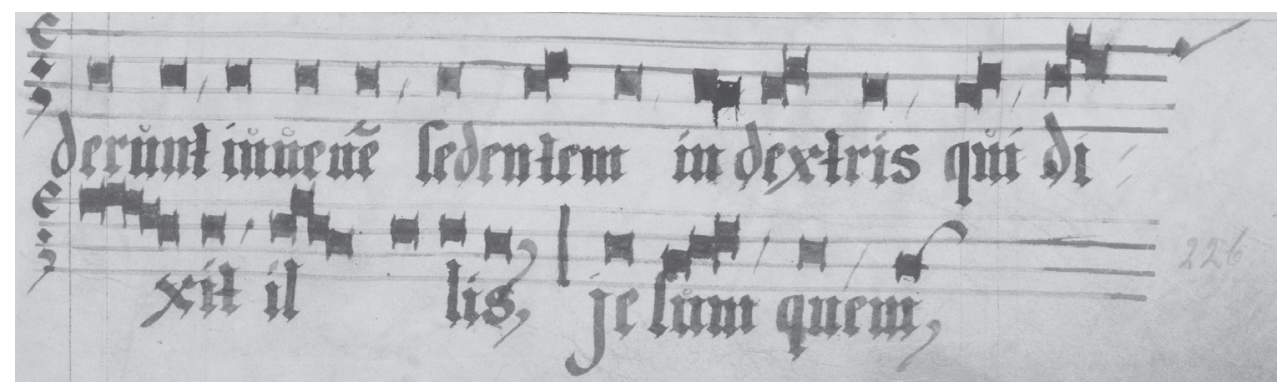

Przykład 7: 220r dolny margines

Analiza paleograficzna późniejszych wpisów z notacją kwadratową - szczególnie tekstu słownego - wskazywałaby na ich przynależność do kilku rąk skryp-

${ }^{24}$ Por. H.E. SowUlewska, Liturgiczno-muzyczna tradycja Tyńca: na podstawie porównania wariantów melodycznych, „Studia Theologica Varsaviensia” 25 (1987), nr 1, s. 15-40. 
torskich oraz odmienny czas sporządzania, dokumentując jednocześnie ciągłą praktykę stosowania tego rękopisu w życiu liturgicznym mnichów (zob. zapisy na dolnych marginesach f. 91v, 119r, 220r).

Inny rodzaj pisma pojawiający się dość często na marginesach czy też we fragmentach palimpsestowych antyfonarza to zapis wywodzący się z późnej notacji krakowskiej, który stanowi system neum mieszanych metzeńsko-gotyckich (tabela 2, zob. także: il. 3) ${ }^{25}$.

Tabela 2

\begin{tabular}{|c|c|}
\hline punctum & \\
\hline pes & \\
\hline clivis & \\
\hline porrectus & \\
\hline torculus & \\
\hline climacus & \\
\hline scandicus & \\
\hline strophici & \\
\hline
\end{tabular}

Podstawową jednostkę tej notacji stanowi romboidalne punctum. Pes jest złożony z punctum i virgi z drugą główką nutową po prawej stronie laseczki notowanymi

${ }^{25}$ Przykładowe miejsca występowania tej notacji: f. 129r, 130v, 131v, 139v-140r, 146v, $148 \mathrm{r}-148 \mathrm{v}, 157 \mathrm{r}, 158 \mathrm{v}, 159 \mathrm{r}, 169 \mathrm{r}, 170 \mathrm{r}, 172 \mathrm{v}, 180 \mathrm{r}, 181 \mathrm{r}, 193 \mathrm{r}, 194 \mathrm{r}, 200 \mathrm{r}, 202 \mathrm{r}-204 \mathrm{r}, 205 \mathrm{r}$, 219r-219v, 287r, 290v, 340v-341r. 
zasadniczo rozdzielnie, w przypadku mniejszych interwałów laseczka schodzi poniżej pierwszego rombu. Neuma clivis występuje w formie metzeńskiej, z końcówką laseczki przekształconą w romb wyraźnie oznaczającym miejsce drugiego dźwięku, oraz niemieckiej, stosowanej jedynie w złożeniach neumatycznych - nigdy się nie zdarza izolowana. Porrectus obejmuje metzeńską clivis i virgę, z kolei torculus punctum i clivis niemiecką. Neuma climacus najczęściej jest notowana poprzez połączone ze sobą clivis - same metzeńskie, bądź pierwszą niemiecką, a pozostałe prostokątne - rzadziej jako schodzące puncta. Dla scandicus charakterystyczne jest zestawienie pes i virgi, czasem postępujących puncta i z rzadka puncta z pes na szczycie neumy. Podobnie jak w późniejszych zapisach notacją kwadratową, do ostatniego dźwięku, kończącego pewien odcinek muzyczno-słowny, dostawiano znak przecinku (na wysokości dźwięku poprzedzającego, zob. f. 157r, 158v).

Jest to dość typowy przykład późnej notacji krakowskiej z rozłącznym traktowaniem poszczególnych elementów (poza clivis). W stosunku do metzeńsko-gotyckiej notacji pierwszej karty antyfonarza wyraźnie zarysowują się dwie tendencje właściwe późnej notacji gotyckiej - zdecydowane pogrubienie laseczki virgi oraz oddzielny zapis niektórych komponentów poszczególnych neum (np. pes).

Prawdopodobnie tenże sam skryptor poczynił także zapisy na niektórych kartach graduału opata Mścisława - np. f. 297v, 298r, 299r, 303v.

Podobną notację znajdujemy w co najmniej pół wieku późniejszym graduale tynieckim fundacji opata Macieja Skawinki (datowany na rok 1460, Pl-Wn 12721 $\mathrm{V})^{26}$. Oba pisma wywodzą się z późnej notacji krakowskiej, nie są jednak tożsa$m^{27}$. Poza wszystkim notacja graduału nie jest jednolita, przy na ogół stosowanej virdze $\mathrm{z}$ główką nutową skierowaną $\mathrm{w}$ prawo - podobnie jak w omawianej notacji antyfonarza - zdarzają się fragmenty z notacją virgi typu Hufnagel (przykład 8a), także pojawia się dwojaki zapis neumy clivis czy torculus - poza formą z ostatnim elementem w kształcie rombu występuje z uciętą na ukos laseczką (przykład 8b); różnica dotyczy także ukształtowania neumy torculus - jej drugiego elementu (przykład 8c i 8d). Ponadto rozłączna notacja poszczególnych elementów neumatycznych nie jest jeszcze konsekwentnie przestrzegana.

Pomimo pewnych różnic, miejscami notacje wydają się znacząco zbliżone do siebie (przykład 9). Bardzo prawdopodobne, iż marginesowe wpisy późną notacją metzeńsko-gotycką antyfonarza oraz graduału opata Macieja Skawinki powstawały w podobnym czasie.

${ }^{26}$ J. Szendrei, Notacja liniowa, s. 229. Rękopis dostępny jest w formie elektronicznej na portalu Polona, https://polona.pl/item/20758744/0/, (1.09.2017).

27 J. Szendrei, Notacja liniowa, s. 221. 


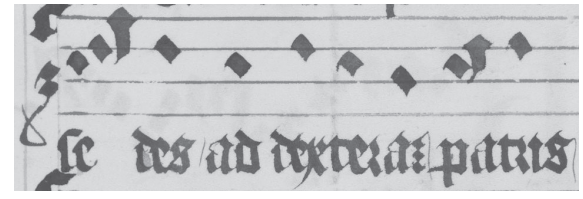

Przykład 8 a: Graduał, f. 3v

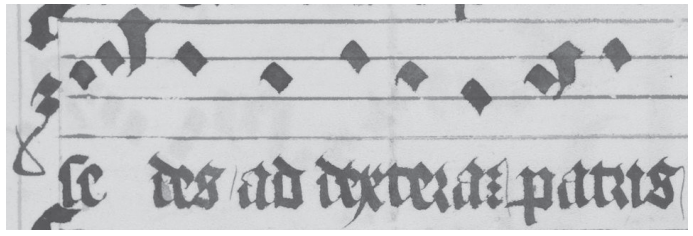

Przykład 8 b: Graduał, f. 17v Graduał antyfonarz

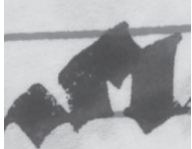

Przykład 8 c: graduał

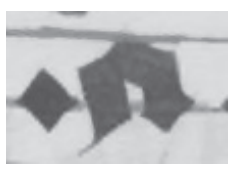

Przykład 8 d: antyfonarz

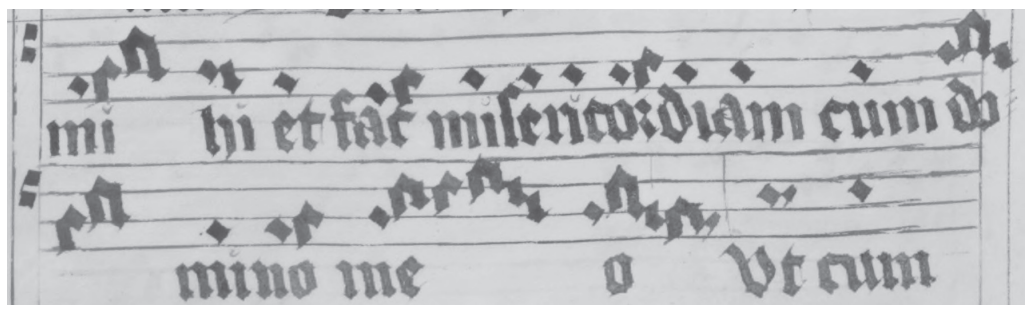

Przykład 9 a: Antyfonarz, f. 131v

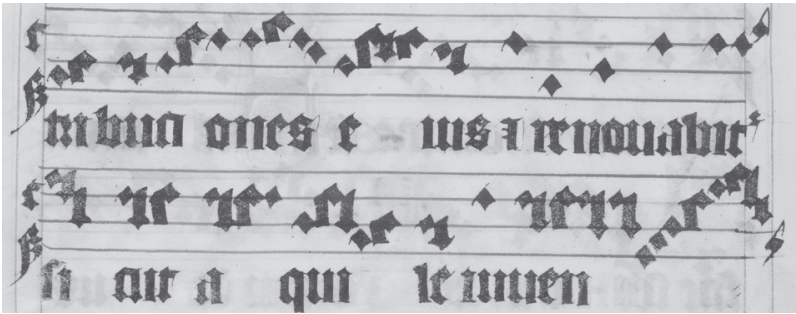

Przykład 9 b: Graduał, f. 70v

Jak można wnioskować z zapisów dodanych już po sporządzeniu księgi, w skryptorium tynieckim nadal były w użyciu oba systemy notacyjne (XV w.) zarówno z neumami gotyckimi, jak i kwadratowymi, a jego powiązanie z praktyką krakowską wydaje się jeszcze bliższe. 


\section{Pismo muzyczne kart dodanych do rękopisu}

Do antyfonarza tynieckiego prawdopodobnie pod koniec XVI w., podczas ponownego oprawiania rękopisu, dołączono siedem kart papierowych z dodanymi responsoriami z Matutinum $^{28}$. Nie zawierają one foliacji i zostały wklejone po następujących kartach: f. 5, f. 138, dwie po f. 150, f. 172, f. 180, f. 284. Najprawdopodobniej zostały spisane specjalnie dla tego rękopisu, o czym mógłby świadczyć zapis na dolnym marginesie folio $181 \mathrm{r}$ - końcówka kompozycji z dodanej karty jest zapisana na marginesie oryginalnej karty rękopisu.

Opisując pismo muzyczne antyfonarza tynieckiego, dotychczasowi badacze pomijali kwestię notacji występującej na dołączonych kartach.

Cały materiał dodany charakteryzuje jednolitość pisma muzycznego (il. 4). $\mathrm{Z}$ pewnością zapis tych responsoriów pochodzi spod ręki jednego skryptora. Podobnie jak w zapisie oryginalnym antyfonarza, liniatura ma kolor czerwony. System liniowy składa się z czterech lub pięciu linii, a na jednym folio znajduje się osiem lub dziewięć systemów i tylko jedno folio liczy dziesięć. Zastosowano tu klucze $c$ i $F$, które występują albo razem, albo tylko jeden z nich (przykład 10).

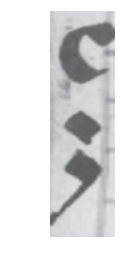

Przykład 10 a

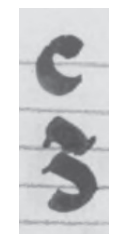

Przykład 10 b

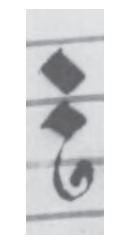

Przykład 10 c

Klucz $F$ z zawiniętym ogonkiem w prawą stronę (przykład 10c) pojawia się tylko jeden raz - na początku utworu i karty (karta po f. 138). Zdarza się także bemol stawiany przed nutami SI oraz $E$. Z kolei, jeśli chodzi o znak kustosza, występuje na końcu niemal każdego systemu liniowego w formie rombowej z unoszącą się małą kreseczką po prawej stronie, najczęściej zakończoną zawiniętym w dół „ogonkiem” (przykład 11a).

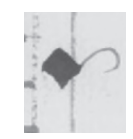

Przykład 11 a

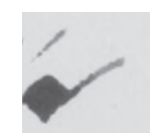

Przykład 11 b

28 Wykaz dodanych responsoriów można znaleźć w pracy Tadeusza Bratkowskiego. T. BRATKOwSKI, Antyfonarz, s. 91. 
W zapisie muzycznym na dodanych kartach stosowane są pionowe kreski - divisio maior (Bratkowski wspomina o występowaniu tu także kresek podwójnych divisio maxima, jednakże tu ich nie znajdujemy) ${ }^{29}$. Ponadto na systemie liniowym występują także krótkie pochylone w prawo kreseczki oddzielające krótkie motywy odpowiadające wyrazom (przykład 12) - podobnie jak w niektórych wpisach nieoryginalnych z notacją kwadratową (por. przykład 7).

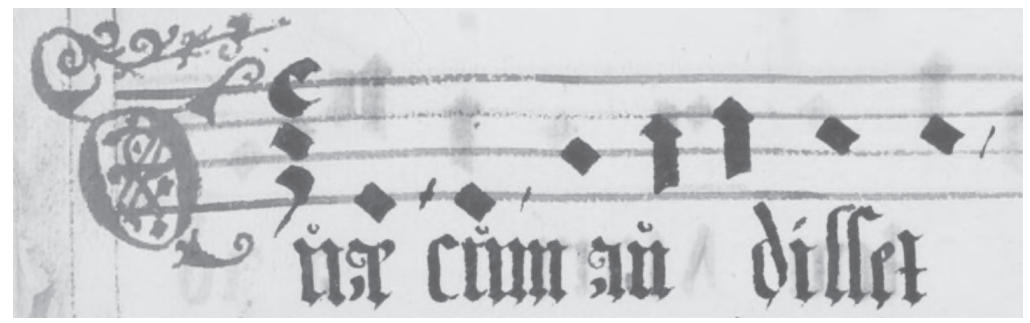

Przykład 12

Jeszcze jednym charakterystycznym elementem tej notacji jest dostawianie przecinka w innym celu niż wskazywanie zjawiska likwescencji. Znak przecinka, swoisty dla neum likwescencyjnych, w tym przypadku występuje w kontekście kadencyjnym - jest dołączany do kadencyjnej neumy w unisonie z jej ostatnim elementem neumatycznym w celu jego uwypuklenia (wydłużenia). Przecinek występuje we wszystkich kadencjach responsoriów i ich wersetów, głównie dołączony jest do clivis (zawsze typu metzeńskiego) i sporadycznie do punctum romboidalnego (przykład 13).

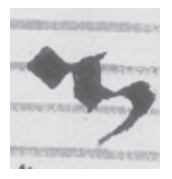

Przykład 13

Pismo muzyczne dołączonego fragmentu stanowi późnogotycka notacja mieszana metzeńsko-niemiecka (system neum mieszanych metzeńsko-niemieckich gotycyzowanych). Neumy są zapisane grubym piórem. Całość pisma charakteryzuje się rozłącznym traktowaniem poszczególnych elementów neumatycznych $(\text { tabela } 3)^{30}$.

${ }^{29}$ Por. T. BRatKowski, Antyfonarz, s. 42-43. W warstwie oryginalnej antyfonarza żadne kreski tego typu nie mają zastosowania.

${ }^{30}$ Rozczłonkowanie neum jest charakterystyczne dla późnej notacji krakowskiej. Por. J. SzENDREI, Notacja liniowa, s. 219. 
Tabela 3

\begin{tabular}{|c|c|}
\hline punctum / tractulus / virga & \\
\hline pes & \\
\hline clivis & \\
\hline torculus & \\
\hline porrectus & \\
\hline scandicus & \\
\hline climacus & \\
\hline & \\
\hline
\end{tabular}

Wśród podstawowych znaków sylabicznych przeważa romboidalne punctum. W neumach kilkudźwiękowych oraz złożeniach neumatycznych jest stosowana virga o kształcie gwoździa (Hufnagel). Dla clivis użyto dwóch form: metzeńskiej prostokątnej i niemieckiej, złożonej z virgi typu Hufnagel oraz drugiego elementu tożsamego dla jej kształtu metzeńskiego. Niemiecką formą tej neumy posłużono się jedynie w złożeniach, nie znajdujemy jej także w funkcji kadencyjnej. Poza clivis, dla kilkudźwiękowych neum zastosowano rozłączny zapis ich poszczególnych elementów. Pes obejmuje romboidalne punctum i virge (typu Hufnagel) zapisane z wyraźną przerwą pomiędzy nimi. Torculus składa się z punctum i niemieckiej clivis, a więc rozdzielny zapis dotyczy dwóch pierwszych elementów neumy. Z kolei neuma porrectus występuje $\mathrm{w}$ dwóch odsłonach - z metzeńską bądź niemiecką clivis, w obu przypadkach trzeci element w postaci virgi Hufnagel jest oddzielony od poprzedzającego elementu neumatycznego. Neumę scandicus notowano albo za pomocą pes i virgi, albo postępujących puncta z virga Hufnagel na górze. Żadna z form nie jest związana $\mathrm{z}$ określoną strukturą interwałową - obie występują zarówno przy ruchu łącznym, jak i przy większych interwałach. Z kolei dla neumy climacus charakterystyczne jest złożenie następujących po sobie clivis - typu metzeń- 
skiego bądź z pierwszą niemiecką i pozostałymi metzeńskimi, zapisanymi w ten sposób, iż drugi element pierwszej neumy jest jednocześnie pierwszym elementem clivis następnej. Można znaleźć także rozdzielny zapis tej neumy w postaci virgi i schodzących puncta bądź samych puncta.

Skryptor sporządzający zapis na kartach papierowych dokonał także poprawek i uzupełnień w kilku miejscach na oryginalnych kartach księgi, przy czym poprawki te dotyczą w dużej mierze niepierwotnej notacji manuskryptu - kwadratowej, ale wpisów późniejszych notacją metzeńsko-gotycką, którą posłużono się już po sporządzeniu księgi, ale jeszcze przed dołączeniem kart papierowych - w takich miejscach mamy do czynienia z podwójnym palimpsestem. Korekty - fragmenty palimpsestowe, zapisy na marginesie, naklejone fragmenty papierowe na kartę pergaminową - zostały dokonane na f. 129r, f. 137v-138r, 139v-140r, f. 148v f., 159 r, f. 170r, f. 183v. Wśród drobniejszych poprawek trzykrotnie chodzi o jedną i tę samą formułę kadencyjną melodii typicznej pierwszego modus (przykład 14).

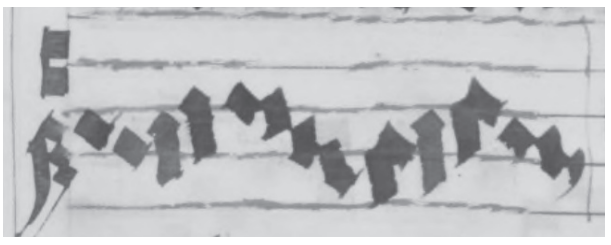

Przykład 14 a: Werset Dominum tuum illum, f. 129r

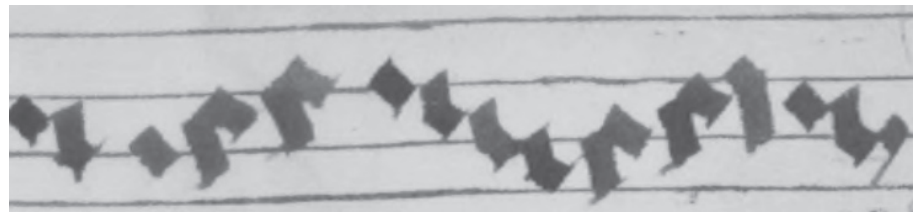

Przykład 14 b: Werset Domine si inveni, f. 148v

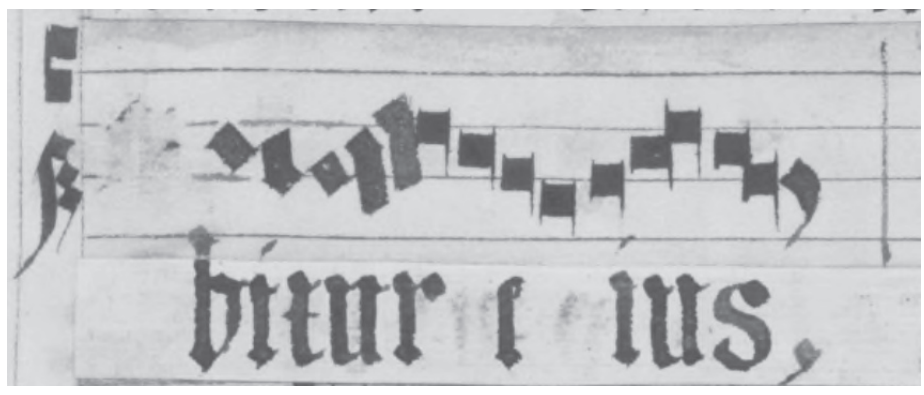

Przykład 14 c: Werset Derelinquat impius, f. 140r

Odstępy pomiędzy kolejnymi komponentami neum są wyjątkowo duże, co nieraz przysparza niemałych trudności w identyfikacji rodzaju neumy oraz odczyty- 
waniu grupowania neumatycznego. Choć rozłączne traktowanie neum jest cechą typową dla późnej notacji krakowskiej ${ }^{31}$, odległości dzielące poszczególne elementy neumatyczne na dodanych XVI-wiecznych kartach są szczególnie duże i decydują o wyjątkowym charakterze tej notacji.

Niemal identyczne pismo z XVI-wiecznych kart dołączonych do antyfonarza znajdujemy także w graduale tynieckim fundacji opata Macieja Skawinki ${ }^{32}$ (f. 1v, 340v, 341r, 341v oraz drobne korekty w niektórych kompozycjach). Podobnie jak w antyfonarzu, zapis ten nie należy do warstwy oryginalnej rękopisu, lecz powstał później możliwe, że pod koniec XVI w., przy ponownym oprawianiu rękopisu.

Drobną różnicę można dostrzec w grafii neumy clivis, a dokładnie: jej drugiego elementu - w antyfonarzu główka drugiego elementu clivis odchodzi od laseczki w prawą stronę, jednocześnie jakby będąc jej przedłużeniem (przykład 15a i 15b), podczas gdy w graduale najczęściej jest zapisana niemal na wprost pod nią (przykład 15c i 15d) zarysowując jeszcze wyraźniej miejsce drugiego dźwięku.

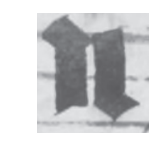

Przykład 15 a

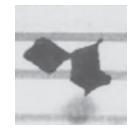

Przykład 15 b

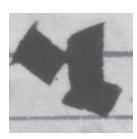

Przykład 15 c

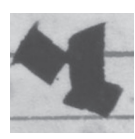

Przykład 15 c

Jeśli zaś chodzi o odstępy pomiędzy elementami neumatycznymi poszczególnych neum, w przypadku notacji graduału są one nieco mniejsze w stosunku do zapisu w antyfonarzu (przykład 16a); zdarzają się też zredukowane do minimum (przykład 16b), nigdy jednak nie pojawia się notacja łączna neumy pes.

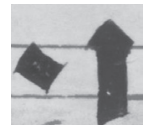

Przykład 16 a

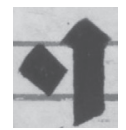

Przykład 16 b

Zapisy obu kodeksów dokumentują przemiany stylistyczne piśmiennictwa skryptorium tynieckiego pod koniec XVI w. W stosunku do wcześniejszych pism

31 J. Szendrei, Notacja liniowa, s. 219.

32 Graduał opata Macieja Skawinki jest przechowywany w zbiorach Biblioteki Narodowej pod sygnaturą: rps $12721 \mathrm{~V}$ (poprzednia sygnatura: akc. 10809); jest dostępny w formie elektronicznej na portalu Polona, https://polona.pl/item/20758744/0/, (1.09.2017). Graduałowi temu jest poświęcona publikacja ks. J. Pikulika: J. PIкULıк, Analiza źródłoznawcza graduału tynieckiego ms. b. s. II z Biblioteki Narodowej $w$ Warszawie, w: TENŻE (red.), Muzyka religijna $w$ Polsce, t. IX, Warszawa 1988, s. 139-242. 
gotyckich, będących w użyciu w skryptorium tynieckim, notacja dodanych kart charakteryzuje się nie tylko rozłącznym notowaniem poszczególnych komponentów neum - co jest zresztą rzeczą dość typową w późnych notacjach gotyckich - ale i konsekwentnym stosowaniem tylko jednej formy virgi typu Hufnagel, podczas gdy w najwcześniejszych zachowanych źródłach - antyfonarzu i graduale opata Mścisława - virga zawsze była notowana z główką po prawej stronie laseczki, a w nieco późniejszych księgach - np. graduale Macieja Skawinki czy XVI-wiecznym antyfonarzu z biblioteki w Staniątkach (ms. 1-4) $)^{33}$ - pojawiała się w obu formach.

Poza zagadnieniem pisma muzycznego kart dołączonych do antyfonarza tynieckiego kwestią być może bardziej w tym przypadku istotną jest opracowanie muzyczne dodanych kompozycji, to jest ich melodie, ze wstępnych badań bowiem wynika, iż niemal wszystkie responsoria posiadają melodie odmienne od tych, które otrzymują w zachodnich i polskich źródłach ${ }^{34}$. Wskazane są jednak dalsze badania uwzględniające liczną grupę ważniejszych źródeł, zarówno zachodnich, jak i polskich. Problem szaty muzycznej wykracza poza zakres niniejszego artykułu; niewątpliwie melodie dodanych responsoriów powinny stać się przedmiotem badań.

Liczne i różnorodne zapisy muzyczne w antyfonarzu opata Mścisława powstałe już po sporządzeniu księgi (korekty, palimpsesty, zapisy na marginesach) oraz dołączone pod koniec XVI w. karty z responsoriami wraz z zasadniczym trzonem księgi - jej częścią pierwotną, oryginalną - współtworzą historię księgi. Dokumentują nie tylko praktykę muzyczno-liturgiczną mnichów benedyktyńskich w Tyńcu, ale i historię piśmiennictwa skryptorium tynieckiego przez wielu lat.

Zestawienie notacji warstwy oryginalnej antyfonarza (kwadratowej i metzeńsko-gotyckiej z f. 1r) z pismem muzycznym nieco starszego graduału tejże fundacji wskazuje na silny związek tych zapisów. Najstarsze zachowane liturgika tynieckie (antyfonarz i graduał opata Mścisława) z jednej strony dają świadectwo współistnienia trzech odmiennych systemów notacyjnych w skryptorium tynieckim: notacji metzeńsko-gotyckiej, ,tynieckiej” (rombowo-kwadratowej) oraz kwadratowej, z drugiej zaś dokumentują swego rodzaju ewolucję pisma muzycznego w tym

${ }_{33}$ Antyfonarz jest datowany na 1535 r., został sporządzony w skryptorium tynieckim. Por. T. BRATKOWSKI, Officium divinum de tempore $w$ rękopiśmiennych antyfonarzach zakonów benedyktyńskich w Polsce od XV do XIX wieku, Rzeszów 2013, s. 71. Rękopis jest dostępny w formie elektronicznej na stronie internetowej biblioteki opactwa benedyktynek w Staniątkach, http://biblioteka. benedyktynki.eu/ncn/, (1.09.2017).

${ }^{34}$ We wstępnych badaniach dotyczących melodii omawianych responsoriów wzięto pod uwagę źródła - polskie i zachodnie - dostępne na portalu Cantus Index, a także XVI-wieczny antyfonarz (ms. 1-4) ze zbiorów biblioteki siostr benedyktynek w Staniątkach. 
skryptorium na przełomie XIV i XV w. - od notacji metzeńsko-gotyckiej poprzez tyniecką i do kwadratowej notacji antyfonarza ${ }^{35}$. Przemiany poszczególnych neum w ramach pisma muzycznego graduału (czterech wariantów) przedstawia w swojej pracy Bartosz Izbicki. Jego zdaniem stylizacja neum metzeńsko-gotyckich (,wariant IV”) w duchu notacji kwadratowej doprowadziła do ukształtowania się „notacji tynieckiej", z kolei kwadratowe pismo muzyczne antyfonarza byłoby w tym kontekście skrajną fazą stylizacji. Uwzględniając także pismo muzyczne antyfonarza, najważniejsze etapy ewolucji notacji na przykładzie neumy pes można by przedstawić w następujący sposób:

\section{Tabela 4}

\begin{tabular}{|c|c|c|c|}
\hline $\begin{array}{c}\text { notacja } \\
\text { metzeńsko-gotycka } \\
\text { (wariant IV, gradual) }\end{array}$ & $\begin{array}{c}\text { notacja } \\
\text { metzeńsko-gotycka } \\
\text { (antyfonarz, f. lr) oraz } \\
\text { wariant III (gradual) }\end{array}$ & $\begin{array}{c}\text { notacja tyniecka } \\
\text { (wariant I, gradual) }\end{array}$ & $\begin{array}{c}\text { notacja kwadratowa } \\
\text { (antyfonarz) }\end{array}$ \\
\hline
\end{tabular}

Z powyższych zestawień zarysowują się trzy zasadnicze tendencje: wyszczuplenie i wyprostowanie laseczki virga oraz wypoziomowanie główek nutowych neumy. Zarazem wszakże zapisy w liturgikach tynieckich dokumentują koegzystencję różnych form notacyjnych, występujących w księgach naprzemiennie (dotyczy głównie graduału) ${ }^{36}$.

Notacja kwadratowa, prezentująca tę skrajną fazę stylizacji neum, w przyszłości i tak ustąpi miejsca notacjom gotyckim w skryptorium benedyktyńskim. Świadczą o tym liczne zapisy na marginesach, notacja dodanych kart, a także pismo muzyczne późniejszych ksiąg tynieckich (np. Graduał opata Macieja Skawinki). Już na przykładzie zapisów z samego antyfonarza można by zaprezentować przemiany $\mathrm{w}$ piśmiennictwie muzycznym skryptorium tynieckiego w XV-XVI wiekach, odzwierciedlające ogólne tendencje czasu powstania księgi - pogrubienie laseczek oraz rozłączna notacja poszczególnych komponentów neumy (tabela 5, neuma pes).

${ }^{35}$ Metzeńskiego pochodzenia znaków tynieckich dowodzi w swojej pracy Bartosz Izbicki. Zob. B. IzBICKI: Graduat, s. 66-72.

${ }^{36}$ B. Izbicki podaje dokładne miejsca występowania poszczególnych notacji w graduale opata Mścisława. Zob. B. IzBICKI, Graduat, s. 59. 
Tabela 5

\begin{tabular}{|c|c|c|}
\hline $\begin{array}{c}\text { część oryginalna - } \\
\text { XIV/XV }\end{array}$ & $\begin{array}{c}\text { zapisy późniejsze na kartach } \\
\text { antyfonarza }-\mathrm{XV} w .\end{array}$ & dodane karty - XVI wiek \\
\hline & \\
\hline
\end{tabular}

Rzeczą znamienną jest, iż w tym samym skryptorium najpierw można śledzić przemiany form neumatycznych prowadzące ku notacji kwadratowej, a w momencie jej pełnego ukształtowania się - powrót do neum gotyckich.

Antyfonarz, będący jedną z najstarszych zachowanych ksiąg tynieckich, dokumentuje nie tylko własną historię, ale historię piśmiennictwa skryptorium od przełomu XIV/XV w. aż do końca XVI w. Gdy zaś chodzi o oryginalne, pierwotne pismo muzyczne rękopisu, wyjątkowość, którą J. Szendrei przypisuje notacji zasadniczej - kwadratowej, orzec można także o notacji metzeńsko-gotyckiej z pierwszej karty księgi ze względu na jednoczesne zastosowanie w niej rombów oraz cienkich i pionowych laseczek dla virgi, charakterystycznych dla tego rodzaju notacji. 


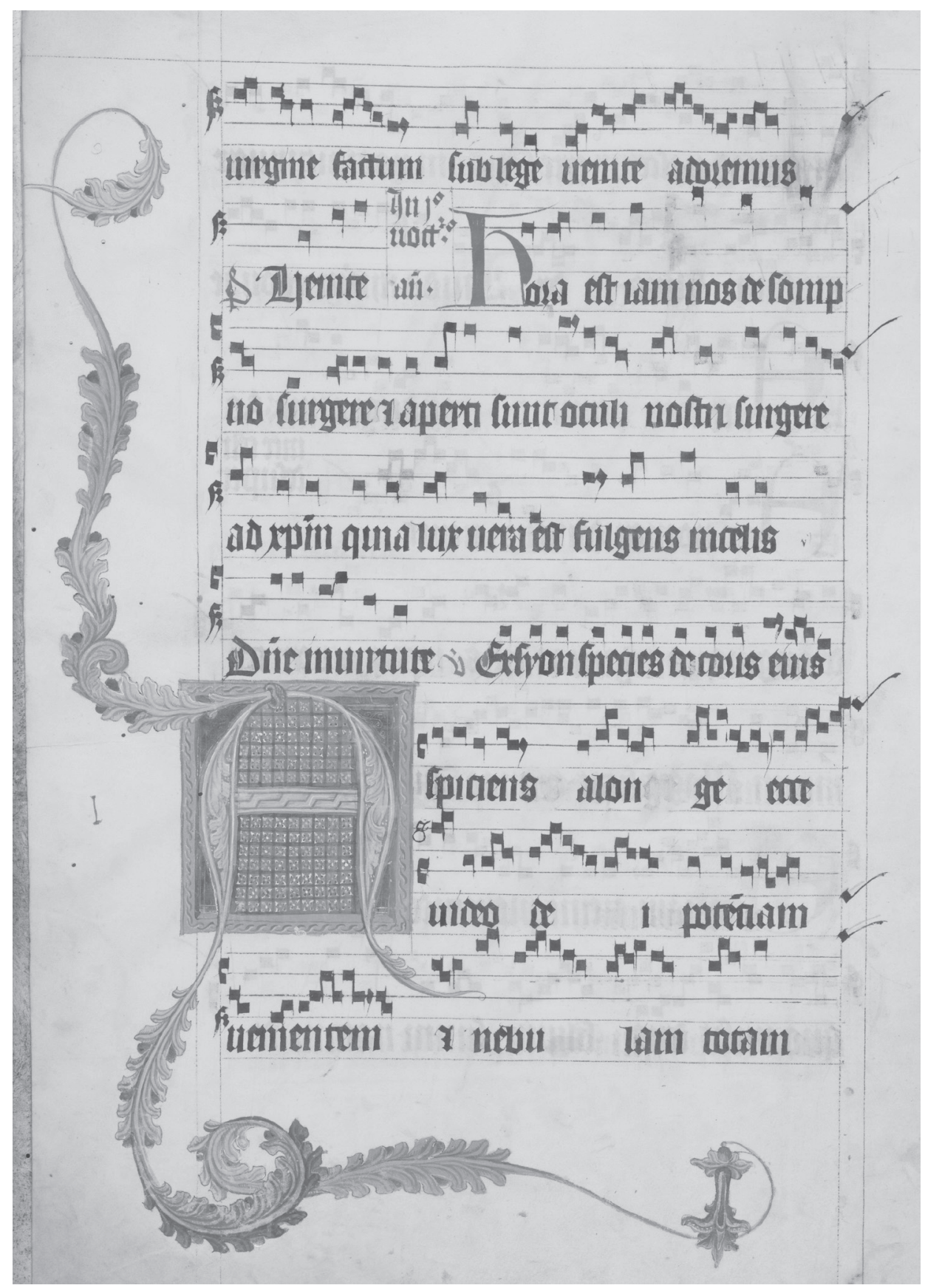

Il. 1: Pl-Wn 12720 V, antyfonarz opata Mścisława, f. 2v - notacja kwadratowa 


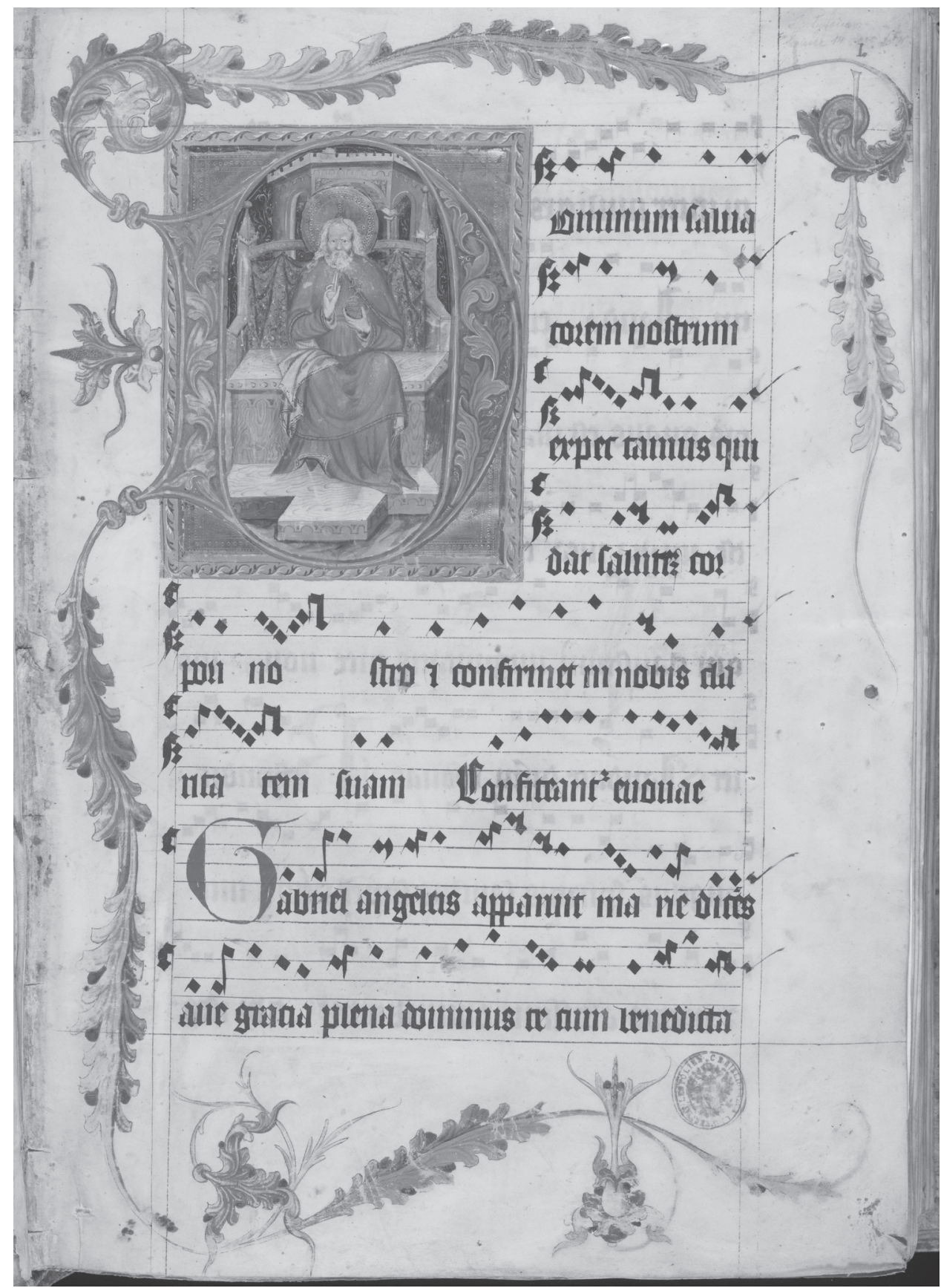

Il. 2: Pl-Wn 12720 V, antyfonarz opata Mścisława, f. 1r - notacja metzeńsko-gotycka 


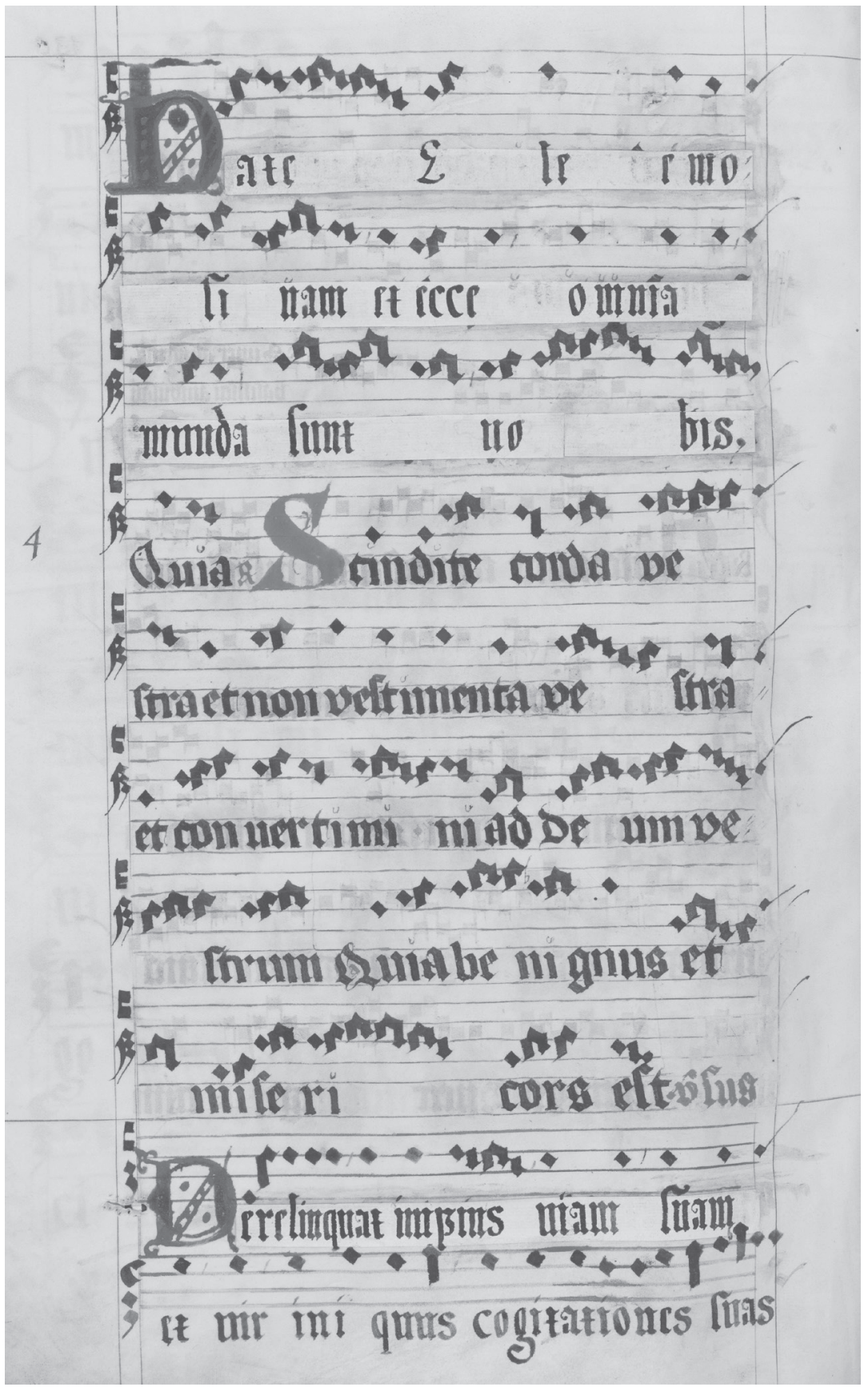

Il. 3: Pl-Wn 12720 V, Antyfonarz opata Mścisława, f. 139V - notacja metzeńsko-gotycka (późna krakowska) 


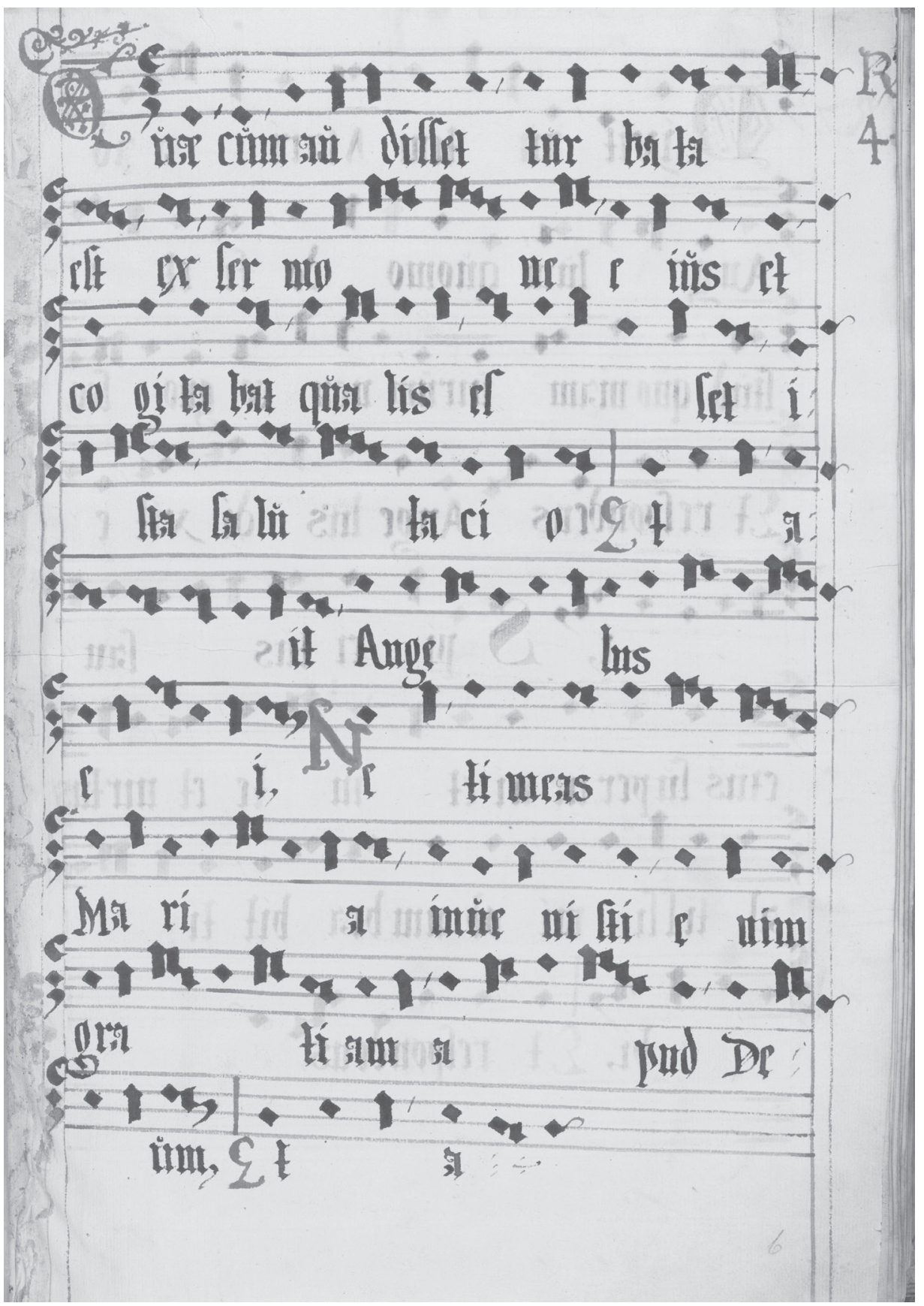

Il. 4: Pl-Wn 12720 V, antyfonarz opata Mścisława, karta po f. 5 - późna gotycka notacja metzeńsko-niemiecka 


\title{
Streszczenie
}

Antyfonarz opata Mścisława (Pl-Wn 12720 V) sprzed 1409 roku, będący jedną z najstarszych zachowanych ksiąg tynieckich, dokumentuje nie tylko swą własną historię, ale i historię piśmiennictwa skryptorium tynieckiego od przełomu XIV/XV w. aż do końca XVI w. Kodeks jest świadectwem zarówno jednej z wówczas używanych notacji muzycznych w skryptorium tynieckim, jak i ewolucji pisma muzycznego w tymże skryptorium, zawierając poza zasadniczą notacją kwadratową, różne formy notacyjne - zarówno w warstwie pierwotnej (oryginalnej) jak i późniejszej (fragmenty palimpsestowe, wpisy na marginesach, dodane karty) - kształtujące się w tym skryptorium na przestrzeni wielu lat. W skryptorium tym najpierw można śledzić przemiany form neumatycznych prowadzące ku notacji kwadratowej, a w momencie jej pełnego ukształtowania się powrót do neum gotyckich. W niniejszym studium przedstawiono wszystkie formy zapisu muzycznego obecne w tej księdze.

Słowa kluczowe: antyfonarz, Tyniec, antyfonarz tyniecki, antyfonarz opata Mścisława, antyfonarz benedyktyński, skryptorium tynieckie, skryptorium benedyktyńskie, benedyktyni, notacja muzyczna, notacja liniowa, notacja kwadratowa, notacja metzeńsko-gotycka, gotycyzowana notacja mieszana metzeńsko-niemiecka, system neum mieszanych metzeńko-niemieckich.

\section{About musical notations in the Tyniec Antiphonary}

\begin{abstract}
Antiphonary of abbot Mścisław (Pl-Wn $12720 \mathrm{~V}$ ) dating from before 1409 year and being one of the oldest surviving Tyniec books, documents not only its own history but also the history of the musical script in the Tyniec scriptorium from the turn of the $14^{\text {th }} / 15^{\text {th }}$ century until the end of the 16th century. The manuscript testifies both one of the musical notations used in the scriptorium of the time, and the evolution of the musical notation in the scriptorium, including apart from the basic square notation various notation forms - both in the original and later layer (palimpsest fragments, margin entries, added cards) - which had been forming in this scriptorium over many years. In the scriptorium, first we can follow the changes of neumatic forms leading to square notation, and at the moment of its full formation, return to Gothic neumes. This study presents all the forms of musical record present in this book.
\end{abstract}


Keywords: antiphonary, Tyniec, an antiphonary from Tyniec, antiphonary of abbot Mścisław, the Benedictine antiphonary, the Tyniec scriptorium, the Benedictine sriptorium, Benedictines, musical notaion, staff notation, square notation, Messine-Gothic notation, Gothicized Messine-German mixed notation, system of "contact neumes".

\section{Bibliografia}

Bratkowski T., Antyfonarz Mścisława z Tyńca. Studium źródtoznawcze, Przemyśl 2009.

BratKowski T., Officium divinum de tempore $w$ rękopiśmiennych antyfonarzach zakonów

benedyktyńskich w Polsce od XV do XIX wieku, Rzeszów 2013

Derwich M., Rola Tyńca w rozwoju monastycznym benedyktynów w Polsce, w: K. ŻurowsKa (red.), Benedyktyni Tynieccy w średniowieczu. [Materiały z sesji naukowej Wawel - Tyniec 13-15 października 1994 r.], Kraków 1995, s. $99-120$.

Feicht H., Muzyka liturgiczna w polskim średniowieczu, w: J. Morawski (red.), Musica Medii Aevi, t. I, Kraków 1965, s. 9-52.

Fегснт H., Studia nad muzyka polskiego średniowiecza, Kraków 1975.

IzBicki B., Graduat tyniecki ms. b. s. I w świetle tradycji europejskiej i polskiej. Studium źródłoznawcze, Warszawa 2006 (mps pracy doktorskiej w Bibliotece UKSW).

Klimecka G., Rękopisy i inkunabuly tynieckie w zbiorach Biblioteki Narodowej w Warszawie, w: K. ŻurowsKA (red.), Benedyktyni tynieccy w średniowieczu, Kraków 1995 s. 261-283.

KLIMECKA G., Tynieckie rękopisy iluminowane w zbiorach Biblioteki Narodowej przykładem benedyktyńskiej kultury piśmienniczej $w X I V-X V w$. w: A. PoBóg-Lenartowicz, M. Derwich (red.), Klasztor w kulturze średniowiecznej Polski, Opole 1995, s. 289-297.

Kopera F., Dzieje malarstwa w Polsce. Średniowieczne malarstwo w Polsce, t. I, Kraków 1925.

MiazGa T., Notacja gregoriańska w świetle polskich rękopisów liturgicznych, Graz 1984.

MarszalsKa J., Biblioteka opactwa benedyktynów w Tyńcu w świetle jej inwenta$r z y$, ,Roczniki Biblioteczne” 41 (1997) z. 1-2, s. 29-42. 
MiodońsKa B., Iluminacje krakowskich rękopisów z 1 pot. XV w. w Archiwum Kapituly Metropolitalnej na Wawelu, Kraków 1967.

Miodońska B., Kodeksy iluminowane benedyktynów tynieckich. Wieki XIV-XV (Uwagi historyka sztuki), w: K. ŻURowsKA (red.), Księga pamiątkowa ku czci Bolestawa Orzechowicza Benedyktyni tynieccy w średniowieczu. Materiaty z sesji naukowej Wawel - Tyniec, 13-15.10.1994, Tyniec - Kraków 1995, s. 243-260.

Miodońska B., Małopolskie malarstwo książkowe 1320-1540, Warszawa 1993.

MorawsKa K., Średniowiecze, Cz. 2, Warszawa 1998.

PIKUlik J., Analiza źródtoznawcza graduału tynieckiego ms. b. s. II z Biblioteki Narodowej w Warszawie, w: J. PiкULIK (red.), Muzyka religijna w Polsce, t. IX, Warszawa 1988, s. 139-242.

PIKULIK J., Indeks śpiewów Ordinarium missae w graduatach polskich do $1600 \mathrm{r}$., w: J. PiкULIK (red.), Muzyka religijna w Polsce. Materiaty i studia, t. II, Warszawa 1978, s. 139-271.

Piкulik J., Polskie graduaty średniowieczne, Warszawa 2001.

PIKULIK J., Śpiewy Alleluia de sanctis w polskich rękopisach przedtrydenckich, Warszawa 1995.

PIKULIK J., Śpiewy allelujatyczne na niedziele i święta od Adwentu do Zesłania Ducha Świętego jako kryterium ustalania proweniencji rękopisów polskich, w: J. Wiśniowski (red.), Musica Antiqua. Acta scientifica, t. V, Bydgoszcz 1978, s. 301-313.

PIKULIK J., Śpiewy allelujatyczne na niedziele po Zesłaniu Ducha Świętego jako kryterium ustalania proweniencji polskich rękopisów muzycznych, w: B. Bejze (red.), W kierunku chrześcijańskiej kultury, Warszawa 1978, s. 680-692.

PIKULIK J., Wkład benedyktynów tynieckich do polskiej kultury muzycznej XV wie$k u$, w: T. MichaŁowsKa (red.), Literatura i kultura późnego średniowiecza $w$ Polsce, Warszawa 1993, s. 217-226.

Podlacha W., Historia malarstwa polskiego, Lwów 1913-14.

Podlacha W., Miniatury tynieckich ksiag liturgicznych $w$ Bibliotece Uniwersyteckiej we Lwowie, w: Księga pamiątkowa ku czci Bolesława Orzechowicza, t. II, Lwów 1916.

Rozanow Z., Średniowieczna ikonografia muzyczna, w: J. MorawSKI (red.), Musica Medii Aevi, t. II, Kraków1968.

Sczaniecki P., Katalog opatów tynieckich, „Nasza Przeszłość” 49 (1987), s. 5-244. SCZANIECKI P., Tyniec, Kraków 1981. 
Sowulewska H. E., Liturgiczno-muzyczna tradycja Tyńca: na podstawie porównania wariantów melodycznych, „Studia Theologica Varsaviensia” 25 (1987), nr 1, s. 15-40.

Szendrei J., Notacja liniowa w polskich źródłach choratowych XII-XVI wieku, w: E. Witkowska-Zaremba (red.), Notae musicae artis. Notacja muzyczna w źródtach polskich XI-XVI wieku, Kraków 1999, s. 187-281.

WęCOWski J., Początki chorału benedyktyńskiego w Polsce (968-1150), w: J. MoRAWSKI (red.), Musica Medii Aevi, t. II, Kraków 1963, s. 40-51.

Żurowska K. (red.), Tyniec. Sztuka i kultura benedyktynów od wieku XI do XVIII. Katalog wystawy w Zamku Królewskim na Wawelu, październik - grudzień 1994, Kraków 1994.

Chronologia polska, B. WŁODARSKI (red.), Warszawa 1957.

Inwentarz rękopisów do połowy XVI w. w zbiorach Biblioteki Narodowej, opr. J. KaliszuK, S. SzYller, Warszawa 2012.

Malarstwo gotyckie w Polsce, t. I-III, A. Labuda, K. Secomska (red.), Warszawa 2004.

Nad złoto droższe. Skarby Biblioteki Narodowej, H. TchóRzewsKa-Kabata (red.), Warszawa 2000.

Tyniec. Sztuka i kultura benedyktynów od wieku XI do XVIII. Katalog wystawy w Zamku Królewskim na Wawelu, październik-grudzień 1994, K ŻUROwSKA (red.), Kraków 1994.

https://polona.pl/item/20758739/0/, (1.09.2017)

https://polona.pl/item/20758744/0/, (1.09.2017)

https://polona.pl/item/20758744/0/, (1.09.2017)

http://biblioteka.benedyktynki.eu/ncn/, (1.09.2017)

Irina Chachulska - ur. w 1984 r. w Dieriewnoje na Białorusi. Studia muzykologiczne odbyła w Instytucie Muzykologii KUL, gdzie w 2006 r. uzyskała tytuł magistra muzykologii na podstawie pracy Śpiewy w Imšale Rymskim dla dyjacezij na Belarusi. Mińsk 2004. Studium źródtoznawczo-muzykologiczne napisanej pod kierunkiem ks. prof. Ireneusza Pawlaka, a w 2013 r. obroniła rozprawę doktorską Ornamentacyjne znaczenie elementu oriscus $w$ neumie pressus maior. Przyczynek do estetyki choratu gregoriańskiego, napisaną pod kierunkiem ks. dra hab. prof. KUL Roberta Bernagiewicza. W latach 2006-2011 była także studentką kierunku „muzyka kościelna” na UMFC w Warszawie, uzyskując w 2011 r. tytuł magistra sztuki. W badaniach naukowych zajmuje się problematyką chorałową z zakre- 
su semiologii, estetyki i modalności gregoriańskiej. Aktualnie prowadzi badania skoncentrowane wokół polskich średniowiecznych źródeł chorałowych. W latach 2013-2018 prowadziła zespół wokalny przy Niepublicznym Liceum Ogólnokształcącym Kolegium św. Stanisława Kostki w Warszawie. Od 2017 r. prowadzi zajęcia chorału gregoriańskiego na II Wydziale Uniwersytetu Muzycznego Fryderyka Chopina, a od 2018 pracuje jako adiunkt w Zakładzie Muzykologii Instytutu Sztuki Polskiej Akademii Nauk. Jest członkiem zespołów badawczych Plainchant Sources in Poland - Cantus Planus in Polonia oraz Manuscripta.pl - A guide to medieval manuscript books in Polish collections. 